\title{
Uterine artery hemodynamics in female dogs with open- and closed-cervix pyometra
}

\author{
Hemodinâmica da artéria uterina em cadelas com piometra aberta e fechada \\ Hemodinámica de la arteria uterina en perras con piometra abierta y cerrada
}

Received: 08/10/2021 | Reviewed: 08/22/2021 | Accept: 08/28/2021 | Published: 08/30/2021

\author{
Camila Franco de Carvalho \\ ORCID: https://orcid.org/0000-0002-5233-6548 \\ Universidade Federal de Jataí, Brazil \\ E-mail: camilafcarvalho@gmail.com \\ Andreia Moreira Martins \\ ORCID: https://orcid.org/0000-0002-8283-9779 \\ Universidade Federal de Jataí, Brazil \\ E-mail: andreia_dover@hotmail.com \\ Kyrla Cartynalle das Dores Silva Guimarães \\ ORCID: https://orcid.org/0000-0002-6194-1280 \\ Universidade Federal de Jataí, Brazil \\ E-mail: kynally83@hotmail.com \\ Hellen Chaves Barbosa \\ ORCID: https://orcid.org/0000-0001-8213-021X \\ Universidade Federal de Jataí, Brazil \\ E-mail: chaveshb@gmail.com \\ Daniel Bartoli de Sousa \\ ORCID: https://orcid.org/0000-0003-3209-7911 \\ Universidade Federal de Jataí, Brazil \\ E-mail: daniel_bartoli_sousa@ufg.br \\ Mariana Ferreira da Silva \\ ORCID: https://orcid.org/0000-0001-5114-431X \\ Universidade Federal de Jataí, Brazil \\ E-mail: mariana.ferreira@ discente.ufg.br \\ Nathany Arcaten \\ ORCID: https://orcid.org/0000-0001-9752-8095 \\ Universidade Federal de Jataí, Brazil \\ E-mail: nathanyarcaten@discente.ufg.br \\ Andréia Vitor Couto do Amaral \\ ORCID: https://orcid.org/0000-0001-6406-2372 \\ Universidade Federal de Jataí, Brazil \\ E-mail: andreiavcvet@ufg.br
}

\begin{abstract}
Although pyometra is a common disease, the mechanisms that determine cervical opening remain unknown. Knowing that the vascular structures are crucial in pathophysiology, it was observed need for hemodynamic studies assessing uterine artery of female dogs with pyometra and its relation to the neck opening. Thirty-five female dogs were selected and separate into three groups: control group $(\mathrm{CG})(\mathrm{n}=12)$, open-cervix pyometra group $(\mathrm{OCG})(\mathrm{n}=11)$ and closed-cervix pyometra group $(\mathrm{CCG})(\mathrm{n}=12)$, with the objective of evaluating and comparing the hemodynamic changes of the uterine artery [peak systolic velocity (PSV), end diastolic velocity (EDV), and resistance index (RI)] in female dogs with open- and closed-cervix pyometra and correlate them with measurements of uterine diameter (UD) and endometrial thickness (ET). The correlation analysis showed that, with the exception of PSV, the hemodynamics indices were associated with UD and ET, presenting a moderate and positive correlation between UD and EDV $(\mathrm{r}=$ 0.62 ; $\mathrm{P}<0.01)$, a moderate and negative correlation between UD and $\mathrm{RI}(\mathrm{r}=-0.68 ; \mathrm{P}<0.01)$ and also moderate and negative correlation between ET and RI $(r=-0.62 ; \mathrm{P}<0.01)$. These results suggest that alterations of uterine artery hemodynamics are similar in dog females with open- or closed-cervix pyometra, although the UD and the ET can influence in the uterine perfusion.
\end{abstract}

Keywords: Cervix; Pulsed-wave doppler; Endometritis.

\section{Resumo}

Apesar da piometra ser uma doença frequente, os mecanismos que determinam a abertura cervical permanecem desconhecidos. Sabendo-se que as estruturas vasculares são fundamentais na fisiopatologia, foi observada necessidade de estudos que avaliassem a hemodinâmica da artéria uterina de cadelas com piometra e sua relação com a abertura cervical. Foram selecionadas 35 cadelas, distribuídas em três grupos: grupo controle $-\mathrm{GC}(\mathrm{n}=12)$; grupo piometra aberta - GPA ( $\mathrm{n}=11)$; grupo piometra fechada - GPF $(\mathrm{n}=12)$, com objetivo de avaliar e comparar as alterações 
hemodinâmicas da artéria uterina (velocidade de pico sistólico - VPS; velocidade diastólica final - VED; e índice de resistividade - IR) e correlacioná-los com os valores do diâmetro uterino (DU) e da espessura endometrial (EE). A análise de correlação demonstrou que, excetuando-se VPS, os índices hemodinâmicos sofreram influência do DU e da EE, observando-se, correlação moderada e positiva entre DU e VED ( $r=0,62 ; \mathrm{P}<0,01)$; moderada e negativa entre DU e IR $(r=-0,68 ; \mathrm{P}<0,01)$ e EE e IR $(\mathrm{r}=-0,62 ; \mathrm{P}<0,01)$. Conclui-se que as alterações hemodinâmicas da artéria uterina são semelhantes em cadelas com piometra aberta ou fechada, ainda que o diâmetro uterino e a espessura endometrial ocasionem reflexos na sua perfusão.

Palavras-chave: Cérvix; Doppler pulsado; Endometrite.

\begin{abstract}
Resumen
Aunque la piometra es una enfermedad frecuente, se desconocen los mecanismos que determinan la apertura cervical. Sabiendo que las estructuras vasculares son fundamentales en fisiopatología, fue necesario realizar estudios para evaluar la hemodinámica de la arteria uterina de las perras con piometra y su relación con la apertura cervical. Se seleccionaron 35 perras, distribuidas en tres grupos: grupo control - GC $(\mathrm{n}=12)$; grupo piometra abierto - GPA ( $\mathrm{n}=$ 11); grupo de piometra cerrado - GPF $(\mathrm{n}=12)$, con el objetivo de evaluar y comparar los cambios hemodinámicos de la arteria uterina (velocidad sistólica pico - PSV; velocidad telediastólica - VED; e índice de resistividad - RI) y correlacionarlos con el valores de diámetro uterino (DU) y espesor endometrial (EE). El análisis de correlación mostró que, a excepción de VPS, los índices hemodinámicos fueron influenciados por DU y EE, con una correlación moderada y positiva entre DU y VED $(\mathrm{r}=0,62 ; \mathrm{P}<0,01)$; moderada y negativa entre DU e IR $(\mathrm{r}=-0,68 ; \mathrm{P}<0,01)$ y EE e IR ( $\mathrm{r}=-0,62 ; \mathrm{P}<0,01)$. Se concluye que las alteraciones hemodinámicas de la arteria uterina son similares en perras con piometra abierta o cerrada, aunque el diámetro uterino y el grosor endometrial provocan reflejos en su perfusión.
\end{abstract}

Palabras clave: Cuello uterino; Doppler pulsado; Endometritis.

\title{
1. Introduction
}

Pyometra is a uterine disease that occurs in females of several species, including dogs (Blanco et al., 2018). This disease is one of the most prevalent in this species, affecting animals in the diestrus stage, of middle to old age, without racial preference, and that were exposed to hormonal changes associated with the estrous cycle throughout their reproductive life (Hagman, 2018). Its development is associated with the presence of endometrial hyperplasia, which makes the uterus more susceptible to an inflammatory process and bacterial infection (Schlafer \& Gifford, 2008).

The opening and closing of the uterine cervix vary according to the stage of the estrous cycle, and this can result in changes related to the muscle layer, glandular proliferation, and the presence of inflammatory infiltrate, which is also observed in women that show cervical dilation during delivery (Kupesic et al., 2001; England et al., 2012). Although some studies have tried to define the mechanisms of cervical opening in female dogs with pyometra, it is still unclear which mechanisms are responsible for cervical opening or closing (Prapaiwan et al., 2017).

Such knowledge has clinical relevance because even if the treatment choice is surgical removal of the infectious origin, particularly in cases of closed-cervix pyometra that have high risks of sepsis (Jitpean et al., 2017), the hysterectomy in some female dogs may not be the best approach, such as in breeding stock or in patients who presents concomitant illnesses that momentarily increase the risks of anesthesia and/or surgical procedures and, therefore, require stabilization prior to the surgical procedure (Hagman, 2018).

The abdominal B-mode ultrasound has been widely used to correctly diagnose uterine disorders, and in cases of pyometra, it allows for diagnosis confirmation before the appearance of clinical signs, or establishment as open- or closedcervix pyometra (Kupesic et al., 2001; Hagman, 2018).

The Doppler ultrasound allows for the assessment of the blood flow inside the vessel, such as its presence, blood direction, and blood velocity (Carvalho et al., 2008a). Despite the fact that its association with the B-mode ultrasound is well established in the medical gynecological routine (Kupesic et al., 2001), the use of Doppler ultrasound in female dogs is still the subject of recent studies, as research is still assessing different luminal fluids (Batista et al., 2016), gestational features, and 
uterine involution postpartum (Barbosa et al., 2013, Batista et al., 2018), as well as physiological variations during the estrous cycle (Nogueira et al., 2017).

Although a previous study has shown the importance of vascular structures in the closing of the cervix (GoerickePesch et al., 2010), there is no study to date that has assessed changes in hemodynamics and its relationship with uterine and endometrial changes caused by both open- and closed- cervix pyometra.

Thus, the objectives of this study were to evaluate and compare the hemodynamic indices of the uterine artery in female dogs with open- and closed-cervix pyometra and correlate them with measurements of uterine diameter (UD) and endometrial thickness (ET).

\section{Methodology}

The study was conducted at the Veterinary Hospital of the Federal University of Jatai (VH/FUJ) in Jatai, Brazil. The work was in accordance with the ethical and legal aspects that govern research with live animals, under the protocol $\mathrm{N}^{\circ}$ 008/2018 approved by the Ethics of Animal Use Committee of the Federal University of Jatai.

Animals and experimental groups included thirty-five female dogs of more than one year, and the subjects were selected from clinical services to perform elective ovariohysterectomy or with a definitive diagnosis of pyometra (i.e. after confirmation with ultrasound).

All animals underwent: physical examination (heart rate, respiratory rate, rectal temperature and mucous membrane color, breast lymph node inspection, and abdomen inspection). Presurgical testing (complete hemogram, urea, creatinine, alkaline phosphatase, and alanine aminotransferase) was conducted at the Laboratory of Clinical Analysis of the VH/FUJ with the following measures: $5 \mathrm{~mL}$ of blood collected from the cephalic vein by venipuncture procedure; abdominal B-mode ultrasound, Color Doppler ultrasound (CD) or Power Doppler sonography (PD); and Pulsed-Wave Dopper ultrasound (PW) of the uterine artery.

After these steps, the animals were separated into three groups: Control group (CG): 12 healthy female dogs in the diestrus or early anestrus phase, according to tutor's report in relation to the date of the last estrus, without clinical signs of systemic diseases or uterine changes, which were randomly selected from patients submitted to presurgical testing for elective salpingo-oophorectomy; Open-cervix pyometra group (OPG): 11 female dogs with clinical signs of systemic diseases (fever, apathy, lack of appetite), uterine enlargement, and presence of luminal content diagnosed by ultrasonography, as well as purulent vaginal discharge; Closed-cervix pyometra group (CCG): 12 female dogs with clinical signs of systemic diseases (fever, apathy, lack of appetite), uterine enlargement, and presence of luminal content diagnosed by ultrasonography, as well as absence of purulent vaginal discharge.

The ultrasound evaluations were performed by the same operator, using a Samsung Medison ultrasound equipment, model SonoAce R3, with a multifrequency transducer (Linear 5-12 MHz; Convex 2-8 MHz). The animals were placed in the supine recumbence in a foam cushion, abdominal trichotomy, and the use of ultrasound gel. After the identification and assessment of the uterine horns, measurements were taken for its diameter in cross-section (in $\mathrm{cm}$ ), endometrial thickness (in $\mathrm{cm}$ ) in the middle third of the left horn, and for the presence and echogenic characterization of the luminal content. After that, Dopper ultrasound was performed.

After the identification of the uterine body, the CD or PD option was selected on the device in order to locate and visualize the uterine artery. Then, the PW option was selected, adjusting the sample volume in the center of the vessel, manual correction of the angle of insonation to keep it below $60^{\circ}$, and other technical parameters for the formation and characterization of the waves. After obtaining the stability of the abovementioned options, the spectral analysis was performed. The blood flow parameters: peak systolic velocity (PSV) and end diastolic velocity (EDV) were manually marked on the waves, and the 
Resistance Index [RI = (PSV - EDV)/ PSV] was automatically calculated by the equipment software. Three alternating stable measurements were measured to calculate the mean value and all the B-mode and Doppler ultrasound evaluations that followed current protocol in the literature (Alvarez-Clau \& Liste, 2005; Carvalho et al., 2008a; Matoon \& Nyland, 2015).

The variables UD, ET, PSV, EDV, and IR were submitted to Shapiro-Wilk normality test, analysis of variance (ANOVA), and then the Tukey test, using the weight and age as covariates (Statistical Software $\mathrm{R}-3.6 .0$ ). To evaluate the degree of association between the hemodynamic indices and UD, the data were submitted to correlation analysis using the Pearson method. Data were presented as mean \pm standard deviation and considered significant at $\mathrm{P}<0.05$.

\section{Results and Discussion}

The hemodynamic changes of the uterine artery observed in animals with pyometra were related to UD and ET, although these findings were similar in female dogs with open- and closed-cervix pyometra.

In all groups, the majority of the female dogs did not present a defined breed, and only their weight was considered a variable, which ranged from 4 to $35 \mathrm{~kg}$. The mean weight was equivalent for the CG and CCG $(8.49 \pm 2.21 \mathrm{~kg}$ e $11.55 \pm 2.40$ $\mathrm{kg}$, respectively), but it was statistically different for the OCG (18.19 \pm 2.30$)$ (Figure 1a), suggesting that medium to largesized animals (ranging from 15 to $25 \mathrm{~kg}$ and from 25 to $45 \mathrm{~kg}$, respectively) were more susceptible to open-cervix pyometra. This was noted as five of these animals were medium-sized and three were large-sized, even though it is known that the disease can affect animals of any body size (Jitpean et al., 2012; Hagman, 2018).

In terms of animal age, the CG showed a mean value of $3.85 \pm 0.99$ years (Figure $1 \mathrm{~b}$ ), which was significantly lower compared to the other two groups (OCG and CCG) and is also highlighted by previous studies (Almeida et al., 2016; Batista et al., 2018).

The age range of animals with pyometra was between 2 and 15 years, and even though no significant difference was found between them, the average ages of OCG $(8 \pm 1.03$ years $)$ and CCG $(8.82 \pm 1.07$ years $)$ were similar to those found by other studies, who reported that the susceptibility of pyometra increases with increasing age (Schlafer, et al. 2008; Hagman, 2018). 
Figure 1. (a) Mean ( \pm standard deviation) body weight ( $\mathrm{kg}$ ) of animals evaluated in this study. (b) Mean ( \pm standard deviation) age (years) of animals evaluated in this study. (c) Mean ( \pm standard deviation) uterine diameter (cm) of animals evaluated in this study. (d) Mean ( \pm standard deviation) endometrial thickness $(\mathrm{cm})$ of animals evaluated in this study. Treatment means followed by different letters present a significant difference at the $\mathrm{p}<0.05$ by Tukey's test. $(\mathrm{CG}=\mathrm{control}$ group; OCG $=$ opencervix pyometra group; $\mathrm{CCG}=$ closed-cervix pyometra group).

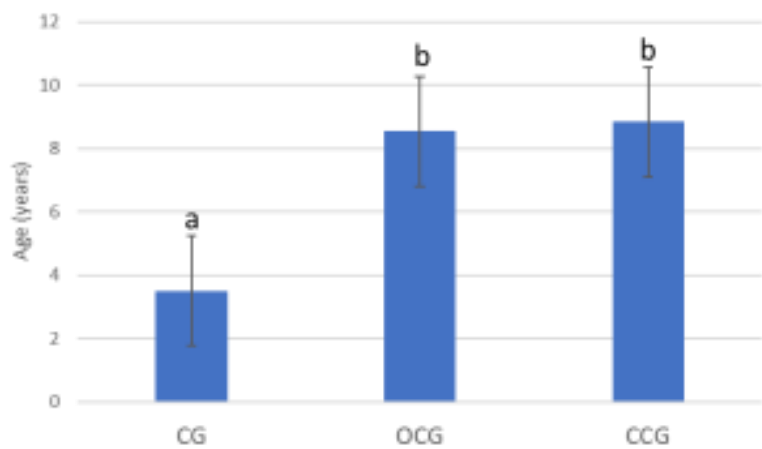

(a)





(c)

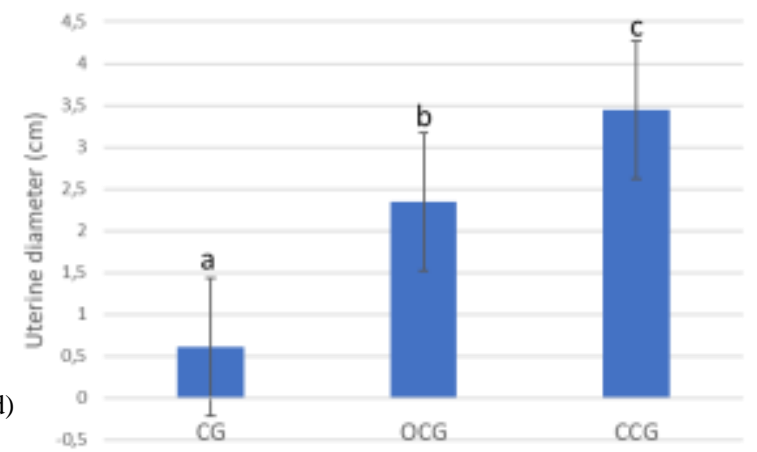

Source: Authors.

However, pyometra was diagnosed in young animals (2 to 4 years old) that received contraceptive medications according to information from the tutors in both groups. This fact also reported in other studies with respect to pyometra in young animals, especially those with a history use of progesterone (Jankowski et al., 2012).

In the CG animals, the uterus had a tubular structure with the diameter ranging from 0.5 to $1.0 \mathrm{~cm}$ (mean diameter: $0.65 \pm 0.26 \mathrm{~cm}$ ) (Figure 1c) and discrete echogenic luminal content. Although the uterine horns diameter may vary according to the dog body size, the number of previous gestations, and the phase of the estrous cycle, in general, the UD is between 0.5 to $1.0 \mathrm{~cm}$ in female dogs in the diestrus and anestrus phase, as found in this study (Matoon \& Nyland, 2015).

In female dogs with pyometra, the UD ranged from 1.15 to $3.6 \mathrm{~cm}$ in the OCG, and 2.64 to $6.5 \mathrm{~cm}$ in the CCG, presenting significant differences in the mean UD between the two groups (OCG: $2.44 \pm 0.27 \mathrm{~cm}$; CCG: $3.40 \pm 0.28 \mathrm{~cm}$ ) (Figure 1c). No reference values were found in the literature that differentiated between open- and closed-cervix pyometra by only measuring the diameter of the uterine horns. However, a pioneering study classified open-cervix pyometra when the UD was lower than $3.0 \mathrm{~cm}$ (Dow 1959), being different than those found in this study. In the present work, higher UD were found in six animals of the OCG, and a UD of up to $3.0 \mathrm{~cm}$ was found in five female dogs of the CCG. Regarding the CCG, the measurements found in this study were similar to those found in the literature, which reported UD ranging from 0.9 to $7.0 \mathrm{~cm}$ (Bigliardi et al., 2004). Other changes can also be seen, such as symmetric or asymmetric, discrete or extended increases in only one or both uterine horns, regardless of open- or closed-cervix pyometra (Veiga, 2017). 
Regarding aspects of the luminal content, hypoechogenic luminal content was found and presented hyperechonogenic points in both groups with pyometra, and it was characterized by high cellularity, which was also found in previous studies (Bigliardi et al., 2004; Matoon \& Nyland, 2015; Singh et al., 2018).

During the B-mode ultrasound in the CG animals, the endometrium was seen as a thin tubular structure and hyperechogenic with thickness ranging from 0.1 to $0.12 \mathrm{~cm}(\mathrm{GC}=0.10 \mathrm{~cm} \pm 0.05)$ (Fig. 1d). These results are in accordance with values found in female dogs without uterine changes and who were in the diestrus and anestrous phases (Matoon \& Nyland, 2015).

In female dogs of the OCG, ET measurements varied between 0.3 to $1.1 \mathrm{~cm}(\mathrm{OCG}=0.41 \mathrm{~cm} \pm 0.27 \mathrm{~cm})(\mathrm{Fig}$. $1 \mathrm{~d})$. There was irregular thickening of the endometrium in all animals, and in only three animals, few cysts measuring about $0.2 \mathrm{~cm}$ were observed. For the CCG, lower ET values were seen in three animals $(\mathrm{ET}=0.1 \mathrm{~cm})$, characterizing endometrial atrophy, and ET of $0.35 \mathrm{~cm}$ was observed for two female dogs, which was the highest measurement in this group $(\mathrm{CCG}=0.27 \pm 0.05$ $\mathrm{cm})$. In the animals that had ET greater than $0.2 \mathrm{~cm}$, irregular thickening was also observed but with no cyst.

Higher values of ET were found (OCG: $1.1 \mathrm{~cm}$; $\mathrm{CCG}=0.35 \mathrm{~cm}$ ) for animals that received progesterone in both groups with pyometra, along with irregular thickening of the endometrium. It is known that endometria exposed to successive reproductive cycles or contraceptive medications, especially based on progesterone, undergoes proliferation of endometrial glands due to the production of a growth factor similar to the insulin type 1 (IGF-1), and this has an mitogenic effect and causes hyperplasia with the possibility of cyst formation, also known as cystic endometrial hyperplasia (CEH) (Bigliardi et al., 2004). For some authors, the CEH represents a series of sequential and uninterrupted events until progression and the occurrence of pyometra, being diagnosed through histopathological examination (Dow, 1959). For other authors, the occurrence of $\mathrm{CEH}$ would not be a limiting factor, since female dogs with endometrial atrophy would also have pyometra, as also found in female dogs of the CCG in this study, and this situation was not explained by previous studies (De Bosschere et al., 2001; Matoon \& Nyland, 2015).

To relate these divergences between endometrial changes, a new classification was performed, including discrete uterine changes and the possibility of pyometra with atrophic endometrium or endometrial hyperplasia. This was based on histopathological findings, such as the relationship between endometrium and myometrium, inflammatory reaction, presence of cysts, fibroblast proliferation, and inflammatory infiltrate (De Bosschere et al., 2001). However, in both endometrial situations (i.e. atrophic or hyperplasia), the ultrasonography is able to assess the thickness, integrity, regularity, and presence of cysts (Bigliardi et al., 2004; Matoon \& Nyland, 2015), as also observed in groups with pyometra.

The ET presented no statistical difference between the OCG and CCG, which can be related to the UD at the time of the diagnosis, in which it was not thick enough to cause compression of the endometrium. However, analyzing the behavior of EE within OCG, it was observed that the highest values $(0.4-1.1 \mathrm{~cm})$ were present in the smallest uterine diameters $(2.0-2.8$ $\mathrm{cm}$ ). And conversely, in CCG, the lowest values of EE (values between 0.1 and $0.2 \mathrm{~cm}$ ) were found in the highest values of UD (above $4 \mathrm{~cm}$ ), which is similar to a study carried out by Singh et al. (2018), who reported uterine diameter greater than $5 \mathrm{~cm}$ in female dogs with closed-cervix pyometra, endometrial atrophy, and significant myometrial hypertrophy.

Thus, even though the mean values between the groups were similar, in the present study it was observed that as the uterine diameter increased, the endometrial thickness decreased and further research that includes histopathological analysis to evaluate the endometrial and myometrial aspects is necessary.

In the female dogs of the CG, waves with a semiparabolic velocity profile, continuous flow of high resistance, with distinguished PSV and EDV, and sudden decrease in speed were observed. The waves measured in this study were similar to those reported in previous studies when female dogs were in the diestrus phase (Figure 2) (Alvarez-Clau \& Liste 2005; Almeida et al., 2016, Nogueira et al., 2017). 
Figure 2. Triplex Doppler image of the waveform morphology of the uterine artery observed in the control group, showing patterns of high velocity and resistance, as well as sudden decrease in the systolic peak velocity.

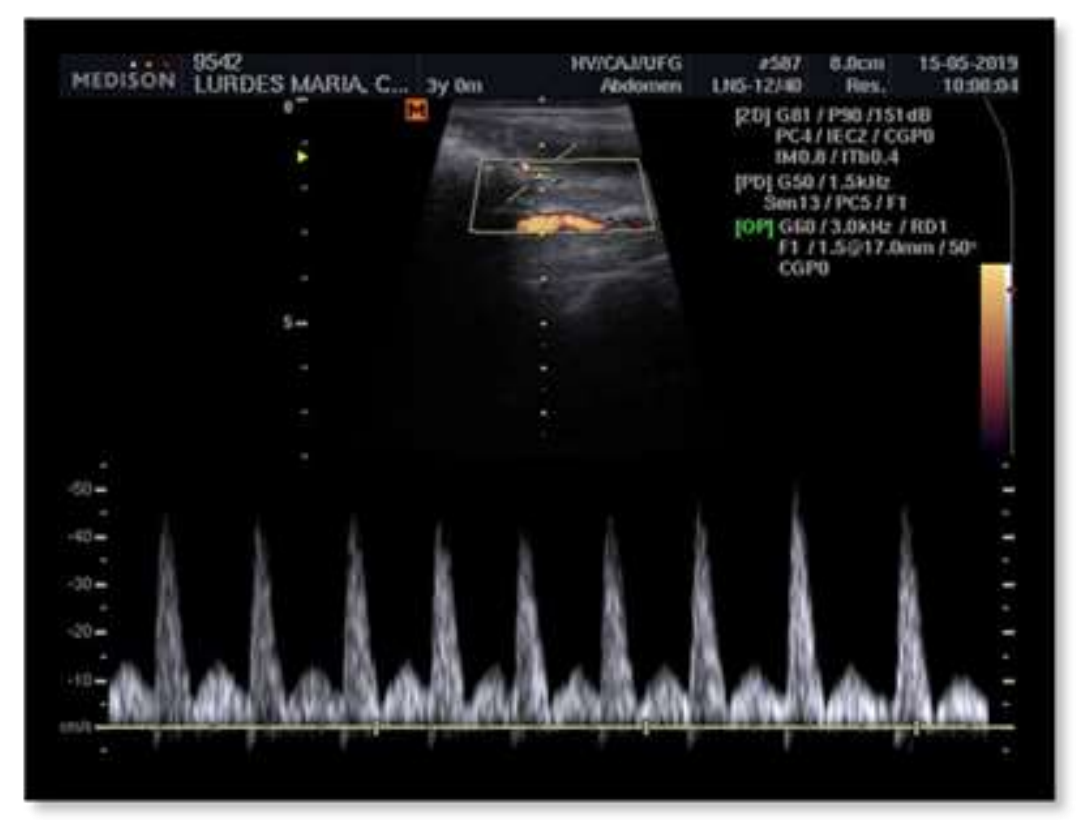

Source: Authors.

A high-speed pattern was found in the CCG and OCG, but it presented low vascular resistance, noted by the presence of continuous diastolic flow and a gradual reduction during the diastole without spectral differences in both groups (Figure 3). These findings of the waveform morphology reflected the reduction of the vascular tone, caused by need for a greater supply of metabolites and oxygen, as well as the presence of vasodilating cytokine in infectious processes such as pyometra (Carvalho et al., 2008b; Almeida et al., 2016, Batista et al., 2016). However, such changes could also be seen in physiological processes in which there is a greater need for blood supply, such as pregnancy and other uterine changes, such as the presence of polyps or neoplasia (Batista et al., 2018).

The PSV mean values were not significantly different among all groups (CG: $32.6 \pm 2.38 \mathrm{~cm} / \mathrm{s} ; \mathrm{CCG}: 29.4 \pm 2.59$ cm/s; OCG: $24.8 \pm 2.28 \mathrm{~cm} / \mathrm{s}$ ) (Fig. 4a). However, the EDV was significantly lower in the CG compared to CCG and OCG (CG: $4.38 \pm 0.69 \mathrm{~cm} / \mathrm{s}$; OCG: $8.48 \pm 0.72 \mathrm{~cm} / \mathrm{s}$; CCG: $10.49 \pm 0.75 \mathrm{~cm} / \mathrm{s}$ ). In contrast, the RI was significantly higher in the CG compared to the CCG and OCG (CG: $0.85 \pm 0.01$; CCG: $0.63 \pm 0.01$; OCG: $0.64 \pm 0.01$ ) (Fig. 4b).

In female dogs without uterine diseases, such as endometrial and spectral changes that can occur in the different phases of the estrous cycle, the hemodynamic indices can also change. 
Figure 3. Triplex Doppler image of the waveform morphology of the uterine artery observed in the opex-cervix pyometra group (a) and closed-cervix pyometra group (b), showing high velocity flow but with low resistance, verified by the gradual reduction of the end diastolic blood velocity
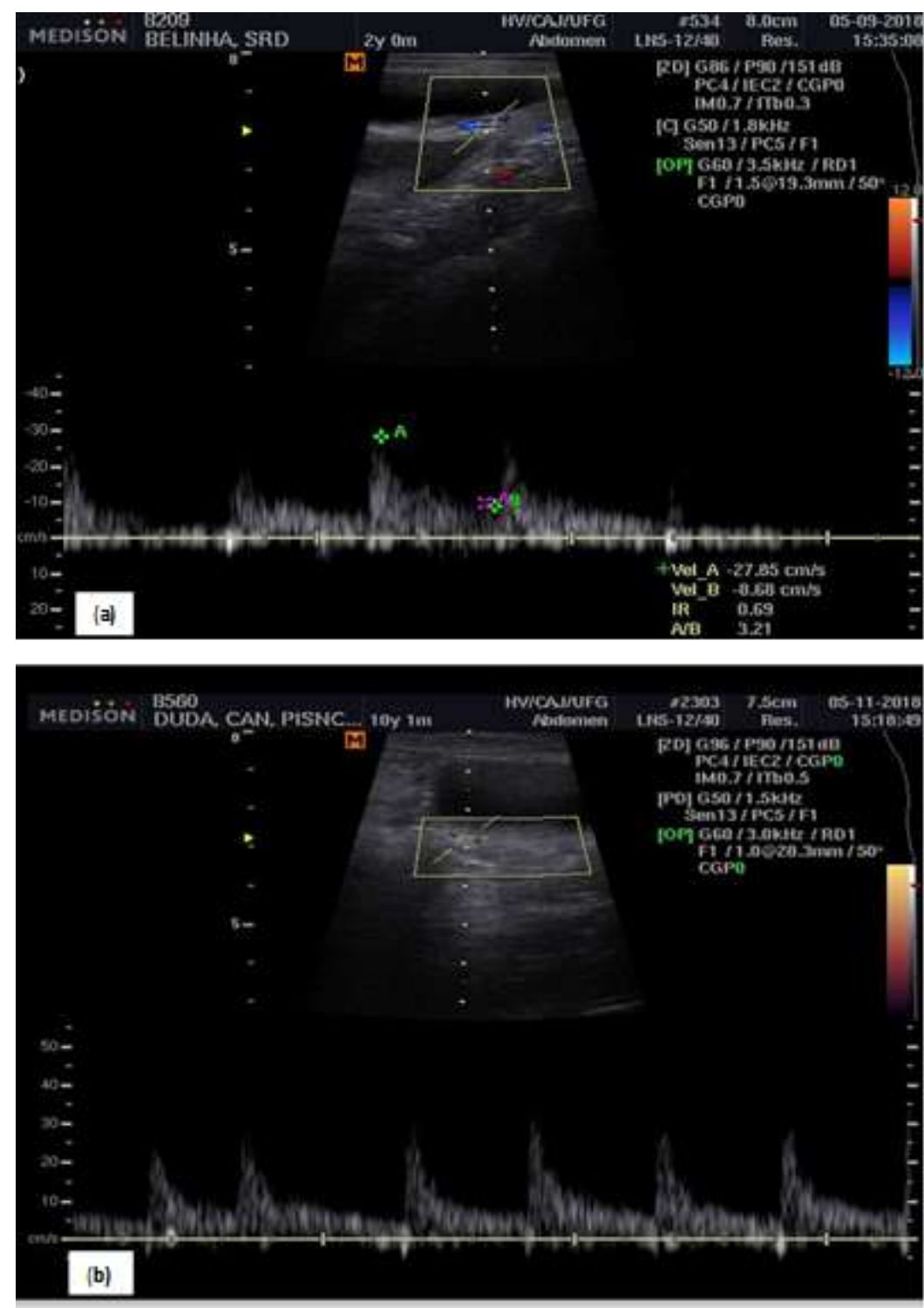

Source: Authors.

These can even be used to verify the fertility and estimate the conception rates in breeding animals (Alvarez-Clau \& Liste 2005; Nogueira et al., 2017).

In addition to the estrous cycle, several factors can also influence the hemodynamic parameters, such as the presence of anemia, which tends to increase the speed of blood flow and, consequently, the PSV, body size, history of previous pregnancies and fertility, age, and the use of sedative medicine that debilitate the cardiovascular system and reduce the Doppler velocimetric indices (Alvarez-Clau \& Liste, 2005). 
Figure 4. (a) Mean ( \pm standard deviation) peak systolic and end diastolic velocity $(\mathrm{cm} / \mathrm{s}$ ) of animals evaluated in this study. (b) Mean ( \pm standard deviation) resistance index of animals evaluated in this study. Treatment means followed by different letters present a significant difference at the $\mathrm{p}<0.05$ by Tukey's test. $(\mathrm{CG}=$ control group; $\mathrm{OCG}=$ open-cervix pyometra group; $\mathrm{CCG}=$ closed-cervix pyometra group).
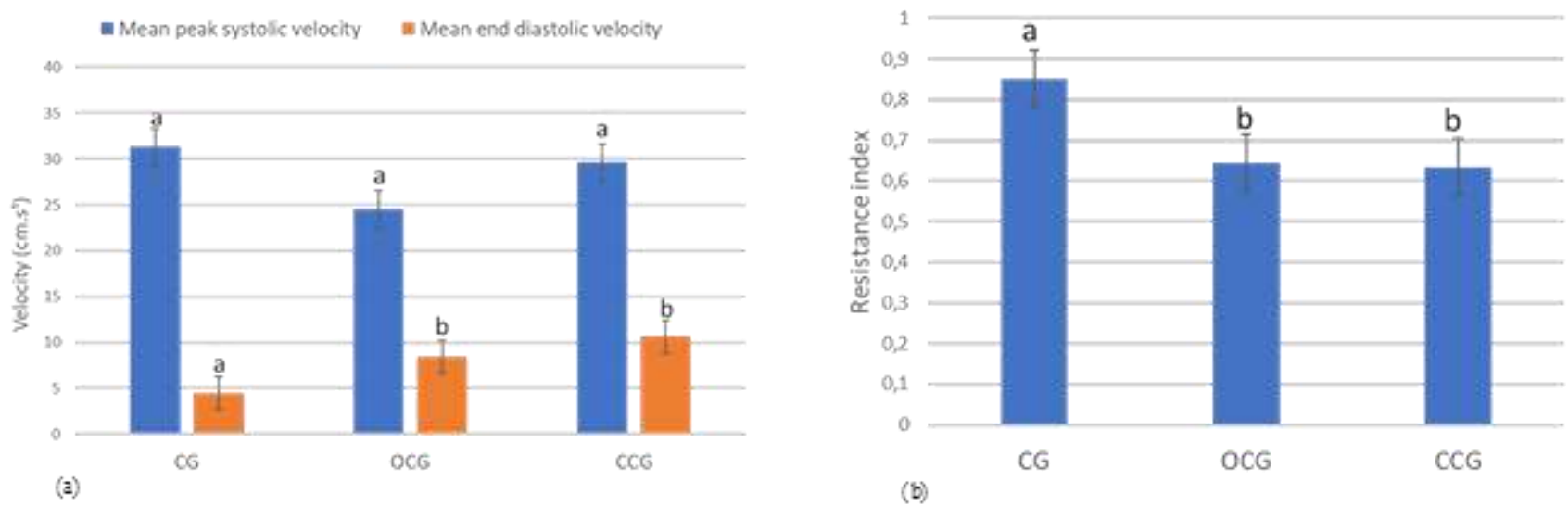

Source: Authors.

In this study, there was no administration of sedative medicines that could reduce the velocimetric parameters, and all the female dogs were healthy and fit for the surgical procedure, with respect to the hematological exams within normal range and without anemia. However, some factors observed in this study were the stresses presented by the animals during the ultrasonography, which can change the heart frequency and the hemodynamic indices. The lack of prior preparation of patients with fasting and the administration of antiphysetics were some difficulties also reported in previous studies (Alvarez-Clau \& Liste, 2005) in addition to the absence of information on the previous reproductive history of all animals. These could be verified to know whether there would be a divergence between the findings among nulliparous, primiparous, and pluriparous. Such occurrences may justify the differences found in this study in relation to others found in the literature (Alvarez-Clau \& Liste, 2005; Almeida et al., 2016; Batista et al., 2016; Nogueira et al., 2017).

Regarding the groups with pyometra, there was no difference in the mean values of the hemodynamic indices between them. Few studies on changes in hemodynamics of uterine artery have been found for the condition (Almeida et al., 2016; Batista et al., 2016), citing only one that made comparisons between open- and closed-cervix pyometra (Batista et al., 2016) and that also did not find differences in the indices between them.

In contrast to findings in OCG (Almeida et al., 2016), as well as both OCG and CCG (Batista et al., 2016), different values of PSV and EDV were found. However, the RI was similar to those reported in this study, indicating that measurements lower than 0.7 can be used to confirm the diagnosis of pyometra and, therefore, differentiate it from other uterine diseases. Previous study on female dogs with closed-cervix pyometra has found greater RI but similar values of PSV to those found in the CCG (Batista et al., 2018); however, these were lower than those found in animals during the diestrus phase, as observed in this study. Because this is an exam that requires ability and experience by the operator, the technical adjustments needed along with the patient collaboration, may help explain differences observed among other studies (Carvalho et al., 2008b; Matoon \& Nyland, 2015).

Across the entire dataset, there was a positive and significant correlation between the EDV and ET $(r=0.62 ; \mathrm{P}<0.01)$ and negative and significant correlation between RI and ET $(r=-0.68 ; \mathrm{P}<0.01)$. Previous research has also found a negative correlation between RI and ET (Almeida et al. 2016). These results showed that the accumulation of purulent material influenced the uterine perfusion, a fact that was also reported in previous studies that evaluated acute-phase protein in female 
dogs with pyometra (Jitpean et al., 2014). This confirmed that the closed-cervix pyometra presented higher values and, consequently, higher intensity in the inflammatory process.

This fact can also be confirmed by the correlation between EDV and UT, as it was inferred that higher values observed in diastole resulted in greater blood flow and, consequently, lower resistance (Batiste et al., 2016). This was also seen in this study, where both OCG and CCG showed higher EDV when compared to CG.

However, when analyzing similar values of ET in both groups $(3.15 \mathrm{~cm})$, an EDV of $15.14 \mathrm{~cm} / \mathrm{s}$ in the OCG and 5.86 $\mathrm{cm} / \mathrm{s}$ in the CCG was observed, suggesting that other factors can also influence the parameters of uterine hemodynamics, and this shows that both forms of pyometra (i.e. open- and closed-cervix) trigger important local and systemic response for the affected organism.

The ET also showed negative and significant correlation with RI $(r=-0,62 ; \mathrm{P}<0,01)$. The interaction between toll-like receptors, found in the endometrium, and lipopolysaccharides found in the cell wall of bacteria, especially Escherichia coli, activate the inflammatory sequence. Then, this triggers the release of interleukin and tumor necrosis factor, important cytokines that also change the uterine blood flow (Jursza-Piotrowska et al., 2016). However, such information contrasts that reported in Singh et al. (2018), in which the atrophic endometrium would be responsible for greater expression of inflammatory markers and hemodynamic changes.

In consideration of the above, it must be highlighted that, even though pyometra is one of the most common diseases in veterinary practices, the mechanisms that can influence the cervical opening and the hemodynamics of uterine artery are still unknown, and more studies are needed for a complete diagnostic clarification.

\section{Conclusion}

It is concluded that although vascular structures can play an important role in cervical patency, the hemodynamic aspects of the uterine artery in dogs with pyometra that relate to waveform morphology and Doppler velocity index were similar in both open- and closed-cervix pyometra, even though the UD and UT have an influence the uterine perfusion.

\section{References}

Alvarez-Clau, A., \& Liste, F. (2005). Ultrasonographic characterization of the uterine artery in the nonestrus bitch. Ultrasound in medicine \& biology, 31(12), 1583-1587. https://doi.org/10.1016/j.ultrasmedbio.2005.08.003

Barbosa, C., de Souza, M. B., de Freitas, L. A., da Silva, T. F., Domingues, S. F., \& da Silva, L. D. (2013). Assessment of uterine involution in bitches using Bmode and Doppler ultrasonography. Animal reproduction science, 139(1-4), 121-126. https://doi.org/10.1016/j.anireprosci.2013.02.027

Batista, P. R., Gobello, C., Rube, A., Barrena, J. P., Re, N. E., \& Blanco, P. G. (2018). Reference range of gestational uterine artery resistance index in small canine breeds. Theriogenology, 114, 81-84. https://doi.org/10.1016/j.theriogenology.2018.03.015

Batista, P. R., Gobello, C., Rube, A., Corrada, Y. A., Tórtora, M., \& Blanco, P. G. (2016). Uterine blood flow evaluation in bitches suffering from cystic endometrial hyperplasia (CEH) and CEH-pyometra complex. Theriogenology, 85(7), 1258-1261. https://doi.org/10.1016/j.theriogenology.2015.12.008

Bigliardi, E., Parmigiani, E., Cavirani, S., Luppi, A., Bonati, L., \& Corradi, A. (2004). Ultrasonography and cystic hyperplasia-pyometra complex in the bitch. Reproduction in domestic animals = Zuchthygiene, 39(3), 136-140. https://doi.org/10.1111/j.1439-0531.2004.00489.x

Blanco, P. G., Rube, A., López Merlo, M., Batista, P. R., Arioni, S., López Knudsen, I., Tórtora, M., \& Gobello, C. (2018). Uterine two-dimensional and Doppler ultrasonographic evaluation of feline pyometra. Reproduction in domestic animals = Zuchthygiene,53 Suppl 3, 70-73. https://doi.org/10.1111/rda.13324

Carvalho, Cibele Figueira, Chammas, Maria Cristina e Cerri, Giovanni Guido. Princípios físicos do Doppler em ultra-sonografia. Ciência Rural [online]. 2008a, v. 38, n. 3 pp. 872-879. Disponível em: <https://doi.org/10.1590/S0103-84782008000300047>.

Carvalho, Cibele Figueira, Chammas, Maria Cristina e Cerri, Giovanni GuidoMorfologia duplex Doppler dos principais vasos sanguíneos abdominais em pequenos animais. Ciência Rural [online]. 38(3), 880-888. https://doi.org/10.1590/S0103-84782008000300048.

De Bosschere, H., Ducatelle, R., Vermeirsch, H., Van Den Broeck, W., \& Coryn, M. (2001). Cystic endometrial hyperplasia-pyometra complex in the bitch: should the two entities be disconnected? Theriogenology, 55(7), 1509-1519. https://doi.org/10.1016/s0093-691x(01)00498-8

DOW C. (1959). Experimental reproduction of the cystic hyperplasia-pyometra complex in the bitch. The Journal of pathology and bacteriology, 78, 267-278. 
Enginler, S. O., Ateş, A., Diren Sı̆̆ırcı, B., Sontaş, B. H., Sönmez, K., Karaçam, E., Ekici, H., Evkuran Dal, G., \& Gürel, A. (2014). Measurement of Creactive protein and prostaglandin F2 $\alpha$ metabolite concentrations in differentiation of canine pyometra and cystic endometrial hyperplasia/mucometra. Reproduction in domestic animals = Zuchthygiene, 49(4), 641-647. https://doi.org/10.1111/rda.12340

England, G. C., Moxon, R., \& Freeman, S. L. (2012). Delayed uterine fluid clearance and reduced uterine perfusion in bitches with endometrial hyperplasia and clinical management with postmating antibiotic. Theriogenology, 78(7), 1611-1617. https://doi.org/10.1016/j.theriogenology.2012.07.009

Goericke-Pesch, S., Schmidt, B., Failing, K., \& Wehrend, A. (2010). Changes in the histomorphology of the canine cervix through the oestrous cycle. Theriogenology, 74(6), 1075-1081e1. https://doi.org/10.1016/j.theriogenology.2010.05.004

Hagman R. (2018). Pyometra in Small Animals. The Veterinary clinics of North America. Small animal practice, 48(4), 639-661. https://doi.org/10.1016/j.cvsm.2018.03.001

Jankowski, G., Adkesson, M. J., Langan, J. N., Haskins, S., \& Landolfi, J. (2012). Cystic endometrial hyperplasia and pyometra in three captive African hunting dogs (Lycaon pictus). Journal of zoo and wildlife medicine: official publication of the American Association of Zoo Veterinarians, 43(1), 95-100. https://doi.org/10.1638/2010-0222.1

Jitpean, S., Ambrosen, A., Emanuelson, U. Hagman R Closed cervix is associated with more severe illness in dogs with pyometra. BMC Vet Res 13, 11 (2016). https://doi.org/10.1186/s12917-016-0924-0

Jitpean, S., Hagman, R., Ström Holst, B., Höglund, O. V., Pettersson, A., \& Egenvall, A. (2012). Breed variations in the incidence of pyometra and mammary tumours in Swedish dogs. Reproduction in domestic animals = Zuchthygiene, 47 Suppl 6, 347-350. https://doi.org/10.1111/rda.12103

Jitpean, S., Holst, B. S., Höglund, O. V., Pettersson, A., Olsson, U., Strage, E., Södersten, F., \& Hagman, R. (2014). Serum insulin-like growth factor-I, iron, C-reactive protein, and serum amyloid A for prediction of outcome in dogs with pyometra. Theriogenology, 82(1), 43-48. https://doi.org/10.1016/j.theriogenology.2014.02.014

Jursza-Piotrowska, E., Socha, P., Skarzynski, D. J., \& Siemieniuch, M. J. (2016). Prostaglandin release by cultured endometrial tissues after challenge with lipopolysaccharide and tumor necrosis factor $\alpha$, in relation to the estrous cycle, treatment with medroxyprogesterone acetate, and pyometra. Theriogenology, 85(6), 1177-1185. https://doi.org/10.1016/j.theriogenology.2015.11.034

Kupesic, S., Bekavac, I., Bjelos, D., \& Kurjak, A. (2001). Assessment of endometrial receptivity by transvaginal color Doppler and three-dimensional power Doppler ultrasonography in patients undergoing in vitro fertilization procedures. Journal of ultrasound in medicine : official journal of the American Institute of Ultrasound in Medicine, 20(2), 125-134. https://doi.org/10.7863/jum.2001.20.2.125

Matoon, J.S., \& Nyland T. G. (2015). Ovaries and uterus. In: Matoon, J. S., \& Nyland T. G. Small animal diagnostic ultrasound. Third edition. WB Saunders; cap. 18, p.634-654.

Nogueira, I. B., Almeida, L. L., Angrimani, D., Brito, M. M., Abreu, R. A., \& Vannucchi, C. I. (2017). Uterine haemodynamic, vascularization and blood pressure changes along the oestrous cycle in bitches. Reproduction in domestic animals = Zuchthygiene, 52 Suppl 2, 52-57. https://doi.org/10.1111/rda.12859.

Prapaiwan, N., Manee-In, S., Olanratmanee, E., \& Srisuwatanasagul, S. (2017). Expression of oxytocin, progesterone, and estrogen receptors in the reproductive tract of bitches with pyometra. Theriogenology, 89, 131-139. https://doi.org/10.1016/j.theriogenology.2016.10.016

Schlafer, D. H., \& Gifford, A. T. (2008). Cystic endometrial hyperplasia, pseudo-placentational endometrial hyperplasia, and other cystic conditions of the canine and feline uterus. Theriogenology, 70(3), 349-358. https://doi.org/10.1016/j.theriogenology.2008.04.041

Singh, L. K., Patra, M. K., Mishra, G. K., Singh, V., Upmanyu, V., Saxena, A. C., Singh, S. K., Das, G. K., Kumar, H., \& Krishnaswamy, N. (2018). Endometrial transcripts of proinflammatory cytokine and enzymes in prostaglandin synthesis are upregulated in the bitches with atrophic pyometra. Veterinary immunology and immunopathology, 205, 65-71. https://doi.org/10.1016/j.vetimm.2018.10.010

Veiga, G. A., Miziara, R. H., Angrimani, D. S., Papa, P. C., Cogliati, B., \& Vannucchi, C. I. (2017). Cystic endometrial hyperplasia-pyometra syndrome in bitches: identification of hemodynamic, inflammatory, and cell proliferation changes. Biology of reproduction, 96(1), 58-69. https://doi.org/10.1095/biolreprod.116.140780

Volpato, R., Martin, I., Ramos, R. S., Tsunemi, M. H., Laufer-Amorin, R., \& Lopes, M. D. (2012). Imunoistoquímica de útero e cérvice de cadelas com diagnóstico de piometra. Arquivo Brasileiro de Medicina Veterinária e Zootecnia [online]. 64, 1109-1117. 